\title{
Islámské bankovnictví a jiná specifika islámského světa
}

\author{
Petr Čermák
}

Vedoucí práce: Ing. Zuzana Stuchlíková

\section{1. Úvod}

Často se říká, že islám není jenom náboženství, ale je to i způsob život. A to takový, který je založen na dodržování pravidel. Mnohá z nich se nám, Evropanům, mohou zdát tvrdá, přísná, ale muslimové sami je tak necítí. Naopak si myslí o naší společnosti, že to, co my nazýváme pokrok, je ve skutečnosti spíše úpadek. Odlišné vnímání světa se projevuje i v ekonomice. Muslimové se v devatenáctém století ocitají tváří v tvář dravému modernímu světu, kterému se musí přizpůsobit, aby je úplně nezadusil. Nemůžou ale překročit jisté hranice, které jsou dané jejich náboženstvím. Je pravdou, že tyto mantinely jsou v různých obdobích bližší či vzdálenější, ale alespoň nějaké minimální hranice tu vždy byly.

Tato seminární práce by chtěla přiblížit islámské bankovnictví, které vychází právě z rozdílného vnímání světa. Fenomén, který se objevil teprve nedávno a který není běžně v povědomí veřejnosti. Přitom to není jev, který by se rozmáhal jen v islámských státech. Islámské banky začínají nabízet své produkty i v Evropě a naopak. Evropské finanční domy si nemohou dovolit přehlížet potencionální skupinu zákazníků a snaží se proniknout na trhy islámských států. Mnoho muslimů v Evropě by dalo přednost účtu, který je v souladu s koránem. Podaří-li se islámským bankám ukázat, že taková možnost tady je, můžou si v Evropě, kde žije čtyřicet miliónů muslimů, výrazně polepšit.

Na konci práce je nastíněno několik málo bodů, které se také týkají náboženského úskalí ve vztahu k výkonnosti islámské ekonomiky.

\section{Islámské bankovnictví}

Úrok a lichva jsou pojmy, nad kterými se spekulovalo od pradávna. V různých společnostech na ně nebyl zas až tak odlišný náhled. První, kdo začal půjčovat s úrokem v letech po Kristu, byli Židé ve středověku. Bibli vyložili tak, že zakazuje půjčovat se ziskem pouze souvěrcům. Do tohoto období spadají i první církevní koncily, které zakazují úročit půjčky. Až za dlouho, zatímco se střídaly doby přísnějšího a volnějšího postoje k tomuto problému, schválila církev existenci bankéřơ, a to až ve 20. století. Rozvoji bankovnictví v Evropě napomohla i reformní hnutí. Protestanti považovali za lichvu úrok v desítkách procent, nikoliv však úrok do deseti procent. První banky v Evropě vznikaly již ve dvanáctém a třináctém století na principu společné investice a dělby výnosu z této investice (obdobná praxe, jakou se snaží provozovat islámské banky dnes). V 17. století se objevují první centrální banky v Amsterodamu a v Anglii.

Stejně tak islám řešil v době svého vzniku otázku, co s lichvou. Korán ji zakazuje. V několika verších a v mnoha hadíthech je napsáno, aby se věřící stranili lichvy. Mají nárok 
na jistinu, ale i tu by neměli vymáhat na osobách, které nemají na zaplacení. Je bohulibé pomoci chudým tak, že jim věřící odpustí dluh. Za lichvu je považována i směna stejného zboží, pokud někdo za víc nekvalitního dostane méně kvalitního zboží. Takovéto výměny se doporučuje dělat přes prodej a následnou koupi, protože jak praví koránský verš: „Bůh však dovolil prodávání a zakázal lichvu. ${ }^{1 \text { “ }}$ Tento verš poskytuje jistý prostor pro obcházení toho, co se korán a hadíthy snažily zakázat.

Je otázkou, jestli korán zakazuje i úrok. Odpověd' na ni není snadná, jelikož mezi uláma (islámskými učenci) nepanuje na toto téma shoda. V koránu se objevuje jev ribá, který je různě vykládán. Obecně je chápán jako lichva, dnes se islámský svět začíná přiklánět k tomu, že je tím myšlen i zákaz úročení.

Nutnost půjčovat si byla v arabském světě samozřejmě také. V průběhu druhého tisíciletí se vyskytovali věřící, kterým zákaz lichvy nedělal problém přejít nebo kteří poskytovali půjčky jako italské banky z 12. a 13. století. Během devatenáctého století se začínají objevovat na Blízkém východě pobočky evropských bank vlastněné cizinci, v kterých taktéž pracovali z velká části občané evropských států. Tyto banky napomáhaly nejenom rozvoji v regionu, ale i v domácí zemi, kam šla část zisků. V tomto století a v další polovině následujícího se ve většině islámských států vytvořila hustá bankovní sí . Až do začátku padesátých let dvacátého století bankám nebyly kladeny překážky (výjimkou je Saudské Arábie). Po druhé světové válce se praxe změnila, Egypt šel jako vzor arabským státům, když schválil v roce 1949 svůj občanský zákoník, kde je např. maximální úrok povolen 7 procent, je zakázán úrok z úroku a celková suma úroku nesmí být větší než jistina. I když sedm procent je suma malá, uvědomíme-li si, že se ceny v letech 1975-1995 znásobily až dvacetkrát. Věřitel by mohl tratit až 10 procent. ${ }^{2} \mathrm{~V}$ druhé půlce dvacátého století začaly převládat konzervativní názory nad reformistickými. Na další vývoj měli vliv teoretici Muhammad Báqir as-Sadr a Muhammad Nejatullah Siddiqi.

\subsection{Muhammad Báqir as-Sadr a Muhammad Nejatullah Siddiqi}

Jsou považováni za průkopníky v oblasti islámské ekonomie a bankovnictví. O tuto problematiku se dosud nikdo zevrubně nezajímal. V roce 1920 nastínil jisté názory Subhí al-Mahmasání a v roce 1955 pak Muhammad Uzair.

Sadr navazuje na diskuzi o ribá, která se vynořila v padesátých letech 20. století. Místo hledání odpovědi, co je ribá, se ale rovnou snaží najít koncepci bankovnictví, která by se bez úroku obešla. Díky tomu, že svou teorii dokázal řádně podložit islámským právem, měla velký ohlas. Konec konců Sadr pokládá islámské právo za hlavní východisko k islámskému ekonomickému systému. Ten Sadr nepovažuje za vědu, nýbrž za doktrínu, která si klade za úkol realitu měnit, ne popisovat. Sadr má jiný pohled na práci než konvenční ekonomie. Práce není zdroj hodnoty, ale prostředek k získání vlastnictví plodu práce. ${ }^{3}$ Podle Sadra není možné, ,aby se jednotlivec dostal k zisku bezpracně. Práce je podstatná pro oprávněnost zisku v islámské teorii (ztotožňuje fungování ekonomiky s právními normami, ekonomická realita je jiná). ${ }^{4}$ “ Aby se zabránilo bezúčelnému hromadění peněz v rukou jednotlivců, navrhuje Sadr 2,5 procentní zakát (daň chudým) ve prospěch státu. Ten má pak financovat velké projekty. Stát má rovněž vlastnit banky podnikající ve stejném duchu jako banky konvenční - zprostředkovávat kapitál tam, kde je ho třeba, a být ziskové. Jejich zisk má pocházet z práce, kterou vykonají, nikoliv díky nahromaděnému kapitálu. Práce je

\footnotetext{
Korán, 2:275/276 (str. 476).

2 Pavel Kohout, Banky podle Alláha.

3 Weberová Babulíková, Gabriela : Islámská ekonomie a bankovnictví,str. 36.

4 Tamtéž.
} 
právě zprostředkování peněz, úročení se bance dovoluje pouze v případě účtů nevěřících, ale i jim má banka zakázáno jinak úročit vklady a půjčky.

Sadr rozděluje vklady na pevné a mobilní. Pevné vklady nelze vypovědět v době kratší jak šest měsíců a vkladatel musí souhlasit s podmínkami mudáraby (transakce, které se účastní vkladatel a banka, viz níže). Není pravděpodobné, že vklad bude mít v budoucnu menší hodnotu $\mathrm{z}$ důvodu diversifikace rizika investic. Mobilní vklady použije banka na zajištění své likvidity a část svým jménem investuje. Nutno podotknout, že mobilní vklad není zdrojem příjmu pro vkladatele. Jedná se zde pouze o půjčku. Podobné dělení užívá i Siddiqi. Sadr navíc zavedl do své teorie spořící vklady, s kterými banka nakládá dle své libosti. Č́st z nich se tedy stane likvidním aktivem banky, část majiteli vydělává.

Siddiqi se zakátem, jak ho navrhuje Sadr, souhlasí. Navíc by měl stát poskytovat i bezúročné půjčky těm, kteří je potřebují, aby se tak zlepšila jejich situace a oni se mohli pak zapojit do výrobního procesu. Zdůrazňuje i nutnost monetární politiky pro zdravý chod ekonomiky. Siddiqi rozvinul vlastní vizi islámské ekonomie, která je založena na podílu na zisku. Siddiqi podrobuje konvenční ekonomiky ostré kritice za jejich úrokový systém. Podle něj je nespravedlností, když si věřitel nárokuje sumu peněz za akt, o kterém není jisté, jak dopadne (což je v rukou Alláha). Kritizuje to, že se bohatší stávají bohatšími, aniž by nutně došlo $\mathrm{k}$ nárůstu $\mathrm{v}$ hospodářství. Siddiqi spatřuje banky jako prostředníky mezi podnikateli a věřiteli, ale částky, které jednotlivé subjekty dostanou, nejsou předem dané. Odvíjí se od toho, kolik nových hodnot, kolik nového bohatství se vytvoří. Dle Siddiqiho je tento systém i logičtější, jelikož nikde není řečeno, že solventní dlužníci budou také ti, kteří vytváří nejlepší projekty. Islámské banky by tudíž měly testovat, zda je podnikatel žádající o půjčku schopný, ne bonitní. Této tezi ovšem součastná praxe neodpovídá. Taktéž nikdy nebylo ověřeno tvrzení, že tento systém není náchylný k inflaci (jak tvrdí Siddiqi), protože neúspěch investice s sebou nese i snížení objemu zboží či služeb. Islámská banka podle Siddiqiho má tedy dva zdroje př́ijmů. Jeden z nich je běžný i v Evropě, což jsou poplatky za služby. Druhý je islámské specifikum, tedy podíl na zisku. Banka může být zisková i na základě poskytování úročených úvěrů. Ty lze, ve shodě se Sardem, poskytnout, jako dř́ive Židé, pouze osobám jiné víry.

Ostatní služby, které běžné banky poskytují a nejsou úročené, nedělají v islámském světě problémy. Jak již bylo zmíněno výše, obchodování se zlatem a stř́íbrem má jediný požadavek na bezkonfliktnost $\mathrm{s}$ islámskými zásadami, a to je ekvivalentnost transakce. Nepřátelsky se staví k prodeji a nákupu obligací.

Oba teoretikové shledávají v souladu s islámským právem směnky. Jinou praxí jsou poplatky ve prospěch banky. Ty jsou legitimní pouze v případě, že banka, na kterou je směnka vystavena, není totožná s bankou, která bude směnku věřiteli proplácet. Siddiqi také neschvaluje eskont směnek.

\section{Rozmach islámských bank}

Teoreticky vzato, první islámská banka vzniká v Pákistánu. Jednalo se o malou venkovskou banku, kterou založili velkostatkáři na poskytování bezúročných půjček. ${ }^{5}$ Fungovala pouze krátkou dobu. V Egyptě v roce 1963 byla založena spořitelna Mit Ghamr. Základem k získání bezúročného úvěru u ní byla daná minimální výše vkladu u spořitelny alespoň na dobu jednoho roku. Mit Ghamr byla aktivní několik let, během kterých pomohla

5 Weberová Babulíková, Gabriela : Islámská ekonomie a bankovnictví, str. 57. 
s financováním projektů bohatších, nakonec kvůli nedostatečné platové motivaci (pramení z nedostatečné ziskovosti) zanikla.

Sedmdesátá léta jsou pro islámské bankovnictví obzvláš důležitá. Rostoucí spotřeba ropy znamenala pro mnohé islámské státy nárůst bohatství. Islámské bankovnictví se dostává z nejistých začátků a podpořeno celkovou islamizací společnosti (navíc oslavou začátku 15. století islámského kalendáře, proběhla v roce 1976) přechází od teorie k praxi. Důležitou roli v tomto procesu hraje Organizace islámské konference, založená v roce 1969 v marockém Rabatu. Na dalších sjezdech vypracovali odborníci zprávu, ve které doporučili nahradit systém postavený na úrocích systémem založeným na spoluúčasti na zisku. Na základě tohoto záměru byla ustanovena Islámská rozvojová banka (ISDB), která začala poskytovat služby od roku 1975 . V součastné době sdružuje 56 států, kterým má pomáhat $\mathrm{s}$ ekonomickým vývojem a půjčovat na různé projekty. Vše má být v soulad s islámským právem. V roce 1981 vznikl Institut pro islámský výzkum a školení, který se stal součástí skupiny ISBD. Jeho posláním je podpořit výuku islámského bankovnictví na univerzitách a motivovat výzkum v této oblasti. Dále je při ISBD činná organizace pro Islámskou spolupráci pro rozvoj soukromého sektoru a od roku 1994 též organizace pro Islámskou spolupráci pojištění investování a exportu (ICIEC). Ne všechny státy, kterou jsou členy ISBD, jsou i členy dalších organizací ze skupiny ISBD. Existuje ještě mnoho dalších méně důležitých institucí, které se zabývají islámským bankovnictvím, a to nejen v islámských státech. V Londýně má např́klad sídlo Institut islámského bankovnictví a pojiš ovnictví, který mimo jiné vydává časopis Nový Horizont.

Dnes je plně islamizované bankovnictví v Íránu, Súdánu a Pákistánu. Přechod není bezbolestný. V Pákistánu nebyla přizpůsobena legislativa, což otvírá právní skulinky těm, kteří by je chtěli zneužít. Navíc je problém s operacemi na vnějších trzích. ${ }^{6}$ Problémy ale přetrvávají i ve státech, kde legislativa přijata byla. Častějším jevem je systém duálního bankovnictví. Stejně jako nad konvenčními bankami, je nutný dohled i nad islámskými bankami, i když to není práce jednoduchá, protože neexistuje jednotný regulační návod. Podle IMF ale potřebná, protože „zdravý bankovní systém je základem makroekonomické stability“. 7

V součastné době působí několik silných islámských bank (Arabská bankovní korporace, Islámská banka Abu Dhabí), které rostou každým dnem. Dle Pavla Kohouta, analytika Finanční skupiny PPF, banky ale půjčují pouze málo výnosným státním podnikům nebo spř́źzněným politikům, u nichž mají jistotu vrácení dluhu. ${ }^{8}$ Banky také raději investují do krátkodobých či střednědobých projekti̊, u nichž se dá snáze odhadnout jejich návratnost. Pavel Kohout dále píše, že ,islámské bankovnictví nepředstavuje samo o sobě pro Západ vážnou výzvu, ale jeho bouřlivý rozvoj v posledních letech je nepř́ijemným signálem, který naznačuje prohlubování propasti mezi západním světem a světem islámu. 9" A už islámské bankovnictví je, nebo není pro Západ vážnou výzvou, faktem zůstává, že aktiva islámských bank rychle narůstají. Tohoto trendu se snaží chytit i konveční bankovní instituce (Citibank, Deutsche Bank, Banque National de Paris a další) tak, že otevírají svoje pobočky fungující na stejném principu. Je to pro ně velice přitažlivý a zatím nenasycený trh.

\footnotetext{
6 Weberová Babulíková, Gabriela : Islámská ekonomie a bankovnictví, str. 63.

7 Luca Errico, Mitra Farahbaksh; http://www.imf.org/external/pubs/ft/wp/wp9830.pdf.

8 Pavel Kohout, Banky podle Alláha.

9 Tamtéž.
} 


\subsection{Hlavní teze islámského bankovnictví}

Paradigma islámského bankovnictví, tak jak by se mělo uplatňovat, zahrnuje pět bodů.

První je zákaz fixního nebo předem domluveného úroku, úrok je nahrazen systémem sdílení zisku a ztrát (Profit Loss Sharing - PLS), kdy výsledek transakce je závislý na výsledku investice, kterou s ní banka podnikne. Riziko je diverzifikováno, poskytovatel financí tedy na některých obchodech tratí, na některých vydělává, což by měl být častější prŕípad. Za druhé je to požadavek operovat $\mathrm{s}$ penězi $\mathrm{v}$ souladu $\mathrm{s}$ islámskými způsoby financování (viz př́slušná podkapitola). Další dva body se týkají ukládání peněz v bance, a to bud' jako investiční vklady (či pevné, jak je nazývají teoretikové Sadr a Siddiqi) či vklady naviděnou (mobilní dle teoretiků). Investiční vklady nejsou garantované a mohou přinést zisk (či ztrátu) a jejich součástí je dohoda o rozdělení zisku (či ztráty), vklady naviděnou garantované jsou, ale zisk nenesou, jde v podstatě o uložení peněz do trezoru. Poslední bod je požadavek použití jednoho ze dvou systémů uložení peněz. První je dvojřadá mudáraba, druhý je systém dvou oken, který požaduje rozdělení vkladu na vklady investiční a vklady naviděnou (na rozdíl od teoretické koncepce, kdy vklady naviděnou mohou být užité i k investování, lze tyto vklady použít pouze na zajištění likvidity).

\subsection{Rozdíly mezi konvenčním a islámským bankovnictví}

Rozdíly ukazuje následující tabulka:

\begin{tabular}{||l|l|l||}
\hline \multicolumn{1}{|c|}{ Islámské bankovnictví } & \multicolumn{1}{|c||}{ Konvenční bankovnictví } \\
\hline $\begin{array}{l}\text { Nominální hodnota vkladů } \\
\text { naviděnou garantována }\end{array}$ & Ano & Ano \\
\hline $\begin{array}{l}\text { Nominální hodnota } \\
\text { investičních vkladů } \\
\text { garantována }\end{array}$ & $\mathrm{Ne}$ & Ano \\
\hline $\begin{array}{l}\text { Systém ekvity, kde kapitál } \\
\text { podstupuje riziko }\end{array}$ & Ano & Ne \\
\hline Míra návratnosti vkladu & Nejistá, negarantovaná & Jistá a garantovaná \\
\hline $\begin{array}{l}\text { Mechanismu regulace } \\
\text { konečné návratnosti vkladu }\end{array}$ & $\begin{array}{l}\text { Záleží na schopnosti } \\
\text { banky/zisku banky z investice }\end{array}$ & $\begin{array}{l}\text { Nezáleží na schopnosti } \\
\text { banky/zisku banky z investicee }\end{array}$ \\
\hline $\begin{array}{l}\text { Podíl na zisku i na ztrátě } \\
\text { aplikován }\end{array}$ & Ano & Ne \\
\hline $\begin{array}{l}\text { Užití PLS a non-PLS } \\
\text { financování }\end{array}$ & Ano & N/A \\
\hline $\begin{array}{l}\text { Užití opatrnosti vzhledem } \\
\text { ručení }\end{array}$ & $\begin{array}{l}\text { Možné při PLS, aby byl } \\
\text { snížen morální hazard, vždy } \\
\text { p̌ri non-PLS }\end{array}$ & Ano, vždy \\
\hline $\begin{array}{l}\text { Bankovní sdílení vkladů } \\
\text { klientů k zajištění } \\
\text { profesionálního investičního } \\
\text { managementu vkladatelům }\end{array}$ & Ano & Ne \\
\hline \hline
\end{tabular}


Poslední řádek tabulky ukazuje první z rozdílů, které stojí za to blíže zmínit. A to, že existuje jistá podobnost mezi islámskými bankami a investičními společnostmi v konvenčních ekonomikách. Obojí vytvářejí zásobu peněz po menších částkách k zajištění profesionálního investičního managementu svých klientů. Rozdíl ale spočívá v tom, že investiční společnosti prodávají část svého kapitálu ve formě akcií, a tak se tedy každý investor podílí na chodu společnosti. Má svá práva a povinnosti. Islámské banky toto dělají na základě vkladů, kdy vkladatel volně nedisponuje penězi, které uložil jako investiční vklad (musí uběhnout určitá lhůta, aby si je mohl vyzvednout z banky), nemá vliv na chod banky či na to, kam investuje peníze. Podílí se na zisku i na ztrátě. S tím souvisí druhá odlišnost. Díky PLS vykazují islámské banky větší odolnost proti externím šokům, ztrátu rozloží na vkladatele, kteří přijdou o své uložené peníze. Třetí rozdíl je, že „se neočekává, že islámské banky budou snižovat úvěrové riziko systematickým vyžadování zástav či jiných záruk jako předpoklad pro udělení PLS prostředku“. ${ }^{10}$ Poslední rozdíl spočívá v odlišnosti dvou systémů užívání peněz. Islámská banka může užívat všechny prostředky, které jsou u ní uložené jako dvojřadá mudáraba, ale v př́padě systému dvou oken může použít pouze peníze, které jsou uloženy jako investiční vklady, zbytek slouží pouze k pokrývání likvidity.

\subsection{Islámské způsoby financování}

\section{1) Financování za užití PLS}

Mudáraba (též qirád, muqárada)

Jedná se o dohodu, při které investor svěřuje své prostředky agentovi, který s těmito svěřenými prostředky hospodaří. Již od středověku jde o nástroj financování, který je plně $\mathrm{v}$ souladu s islámským právem. Investor poskytne své peníze nebo zboží (to musí být ale prodáno, aby nedocházelo k pohybu ceny zboží v čase, což by bylo chápáno jako ribá). Za to mu náleží určitý podíl na zisku, kterého dosáhne podnikatel. Nedocílí-li podnikatel zisku, ale ztráty, nese ji investor celou na svých bedrech (banky nepožadují záruky). Ztrátou podnikatele je jeho vložený čas a úsilí do obchodování. Mudáraba navíc umožňuje, aby získaný kapitál byl dále investován. Věřitel se dohodne s bankou na mudárabě (tzv. neomezená, jelikož není přesně předem daný účel použití/projekt), a banka pak získané prostředky použije, jak uzná za vhodné. Poskytuje-li banka mudárabu (tzv. omezenou, projekt je přesně vymezený, součástí mudáraby je procentuální podíl banky na zisku), uzavírá s klientem přísnou smlouvu, na jejímž základě mu poukáže peníze na účet. $\mathrm{Z}$ tohoto účtu lze ovšem peníze použít jen na předem dojednané obchody. Věřitel má navíc povinnost předkládat bance výkazy a kdykoliv se podrobit auditu z rozhodnutí banky. Ve smlouvě jsou také uvedené různé pojistky proti neplnění termínů a nevyužití celého objemu půjčených peněz, stejně tak povinnost řádně plnit smlouvu (je zde myšleno nemít zlý úmysl). Tyto a další věci vrhají na mudárabu stín pochybností, zda jsou skutečně v souladu s šaríou. Málokdy banka díky všem zárukám tratí. Mudáraba je tedy spís v rozporu s teoretickou koncepcí islámského bankovnictví. I proto není divu, že mudáraby poskytují muslimským klientům i neislámské banky. Mudáraba se používá převážně na financování krátkodobých transakcí v obchodě a službách.

\section{Mušáraka}

Mušáraka je podobná mudárabě, akorát se předpokládá investování všech zúčastněných stran. A stejně tak, jako se podílejí na zisku, se dělí i o ztrátu. Podíl na zisku je bud' dohodnutý, nebo daný ve výši poměru vkladů (liší se dle různých islámských právních

10 Luca Errico, Mitra Farahbaksh; http://www.imf.org/external/pubs/ft/wp/wp9830.pdf, str. 11. 
škol). Podobně se ztrátou s výjimkou, nese-li za ztrátu odpovědnost jeden ze zúčastněných. Ten pak hradí celou ztrátu sám. Chce-li k mušárace přistoupit další partner, smí tak učinit pouze se svolením všech společníků. Banky užívají mušáraky na financování všech typů projektů. Poskytují peníze, vedení pak zajiš ují klienti. Podobně jako u mudáraby banka požaduje různé druhy záruk. Banky nabízejí tř́i druhy mušáraky. Komerční mušáraka se uživá obvykle na nákup zboží či koupi stroje, je časově omezená a v př́padě, že se podnikateli nedaří, může mít ve smlouvě, že mušaraku převezme banka a provede její likvidaci. Mušáraka - klesající účast je taková dohoda, kdy banka postupně snižuje svůj podíl na podniku ve prospěch klienta. Během doby, kdy se účastní podnikání, samozřejmě vydělává dohodnutý podíl ze zisku. Stane-li se banka akcionářem podniku, jedná se o mušáraku - stálou účast.

\section{Muzur'ah, Musaqat}

Muzur'ah je doplněk k mušárace, který se používá v zemědělství. Jde o to, že banka jako spoluúčast poskytuje finance nebo půdu, za což dostává část úrody, př́ípadný zisk se tedy platí naturálně. Jedná-li se mušáraku v oblastí sadařství, nese instrument název musaqat

\section{Př́má investice}

Stejný princip jako u konvenčního bankovnictví. Banka užívá své hlasovací právo, snaží se ovlivnit chod podniku, na kterém je účastna, dle svých představ. Zástupce banky může sedět $\mathrm{v}$ představenstvu. Jediným omezením zde je zákaz investování do oblastí, které jsou v rozporu s šaríou (např. hazard)

\section{2) Financování bez užití PLS}

Užívá se $\mathrm{v}$ prrípadě, kdy se nehodí PLS. Jedná se o půjčky malých obnosů či o spotřební úvěry. Jsou podobné produktům konvenčního bankovnictví. Většinou se liší názvem a několika právními odlišnostmi. $\mathrm{V}$ součastné době se považují za produkty v souladu $\mathrm{s}$ islámským právem, výnos je pevný daný transakcí a neváže se na časovou periodu, tudíž není chápán jako lichva. Za tyto produkty se požadují záruky.

\section{Murábaha (Přirážka)}

Murábaha je třístranná dohoda, kterou banky používají jako nástroj krátkodobého financování. Je to smlouva mezi bankou a klientem, že banka pro klienta nakoupí určité zboží za přirážku od dodavatele (třetí strana). I při této operaci se banky zajiš ují proti prrípadné nepř́zni osudu, napřr. kdyby klient nechtěl zboží převzít. Právě díky zmiňované přirážce (podobně i u další produktů) je murábaha často terčem kritiky, že není v souladu s islámským právem. Díky ní banky rychle a takřka bezpracně dosahují značných zisků. Tento vztah je velmi podobný vztahu dlužník - věřitel, jelikož banka neručí např. za poškození zboží během přepravy. Případné reklamace si musí vyřídit př́ijemce př́ímo s tím, vůči komu je hodlá uplatnit.

\section{Idžára, Idžára wa iqtiná‘ (Leasing, Prodej na splátky)}

Termínem idžára se označuje nám známý pronájem. Pronajímané aktivum ovšem musí být používáno. Je celkem běžně používaná. Obdobou je idžára wa iqtiná', blízký prodeji na splátky. Klient platí po danou dobu pronájem a navíc poukazuje peníze na účet u banky (jsou využívány bankou např. pro mudáraby). Po vypršení doby pronájmu jsou tyto peníze použity na koupi aktiva.

Quad hasan (Benefični piojčka)

Quad hasan je termín, kterým se označuje bezúročná půjčka poskytovaná věřícím, kteří se ocitli v nouzi. Bylo by mylné se domnívat, že je takováto půjčka zadarmo. 
Klientovi se účtuje administrativní poplatek, a např. v př́ipadě půjčce podniku banka získá ve firmě podíl. Administrativní poplatek není závislý na velikosti půjčky nebo na její splatnosti.

\section{Bai' Mua'jja l (Odložená platba)}

Tímto způsobem se prodává na splátky. Jelikož úrok není př́ípustný, musí se to řešit přes jednorázovou dohodu mezi prodejcem a kupujícím (kdy jednou stranou může být banka). Strany se shodnou na částce (která bude většinou vyšší než normální prodejní cena), kterou kupující zaplatí pomocí splátek, nebo někdy později. Placená částka nesmí zahrnovat jakoukoli přirážku za odloženou platbu, jednalo by se o lichvu.

\section{Bai ‘ Salam/Bai ‘ Salaf (Odložená dodávka)}

V tomto případě je uzavřen obchod; kupující zaplatí celou sumu, ale dodávka zboží se uskuteční později. Aby mohl být obchod uzavřen, je nutné, aby mohla být kvalita i kvantita zboží přesně definována. Jedná se tedy často o zemědělské produkty nebo průmyslové zboží.

\section{Jo' alah (Poplatek za službu)}

Jedná se předem daný poplatek za službu, napřr. za profesionální službu, umístění kapitálu či depozitní služby.

\section{4 Účet u nekonveční banky}

Banka svému klientovi připíše peníze na účet vždy na konci finančního roku (islámský lunární). Během roku podniká vlastním jménem, za což si účtuje poplatek. Nedosáhne-li zisku, připíše na účet zákazníka ztrátu, nepočítá si ale žádné poplatky. Služeb se zákazníkům dostává stejných jako v Evropě. Majitelé účtů mohou dostat šekovou knížkou, cestovní šeky atp. Oproti konvenčním bankám požadují ty islámské daleko méně poplatků.

\subsection{Kontrola islámský bank}

Stejně jako je nutné kontrolovat konvenční banky, je žádoucí vykonávat dozor i nad bankami islámskými. Basilejský výbor pro bankovní dohled stanovil směrnice pro dozor nad bankami, bohužel tyto směrnice nejsou vždy plně použitelné i pro islámské banky.

Islámské banky se také nevyhnou riziku, že špatně investují, může existovat špatná tržní disciplína či banku povede špatný management. Ekonomické ztráty pak způsobí ztrátu klientům a zasadí ránu věrohodnosti bank, kterým nebude svěřen dostatek prostředků k tomu, aby mobilizovaly soukromý kapitál a poskytovaly dostatek finančních prostředků pro vhodné investice. Stejně tak nedůvěryhodný bankovní systém nemůže pomoci dosahovat makroekonomických cílů, napřs. neefektivnost platebního systému a monetární politiky.

Jedním ze specifik islámských bank je systém PLS, kdy peníze půjčené bankou se vrátí až po skočení projektu. Pouze pak se dá zjistil zisk a př́ipadný podíl banky na něm. Běžný vkladatel nemá moc ovlivnit, co se s jeho penězi děje, ale měl by vědět, jak banka $\mathrm{s}$ jeho penězi hospodaří, zda mu dává odpovídající podíl na zisku, zda banku vedou odpovědní lidé. Management banky musí peníze dobře investovat a dostatečně diversifikovat riziko, protože neexistují záruky či nárok vrácení peněz, objevuje se zde nebezpečí morálního hazardu. Banky musí mít zkušené zaměstnance. Tyto informace by měly dohlížející instituce poskytovat.

Vkladatel do islámské banky tedy musí víc dávat pozor na své peníze, protože o ně může přijít, monitorování a dohled nad bankami mají mimo jiné za úkol snižovat informační asymetrii. 
Stát by tedy měl zajistit, že existuje právní základ dohledu nad bankami, stejně tak jako zákon stanoví základní bankovní principy a podmínky pro udělení bankovní licence. $\mathrm{V}$ př́padě, že v zemi fungují islámské i konvenční banky, určit, které banky se mohou nazývat islámské.

Standardní systém hodnocení bank CAMEL, který se zabývá pěti složkami (C-kapitál, A-aktiva, M-management, E-př́ijmy, L-závazky), je tedy nutné pro islámské banky upravit, aby celková známka od jedné (výborný bankovní systém) do pěti odpovídala známkám konvenčních bank. V prvním složce CAMELu, kapitálu, je nutné vzít v potaz to, že investice islámských bank jsou rizikovější než bank konvenčních. U těch stanovuje Basilejský výbor pro bankovní dohled, že by měl ukazatel kapitálové přiměřenosti, který se počítá jako vlastní kapitál dělený rizikově váženými aktivy, být větší než osm procent. Běžných je okolo jedenácti procent, islámské banky by ho měly mít ještě o něco větší, přesné číslo záleží na posouzení podmínek finančního trhu i celkového stavu dané země. Stejně je potřeba určit, jak vážit jednotlivé produkty. Váha sto procent by se měla přisoudit mušárace a přímým investicím, rizikovější mudárabě pak nejméně sto procent (čímž se zdůrazňuje její rizikovost), produktům neužívajícím PLS, které jsou méně rizikové, 50 procent. U aktiv je důležité zapracovat fakt, že výsledek mudáraby je známý až po delší době. U likvidity je pak rozdíl oproti konvenčním bankám $\mathrm{v}$ tom, že si islámská banka nemůže vypůjčit od věřitele poslední instance, protože takováto půjčka zahrnuje úrok. Ostatní časti CAMELu jsou obecně aplikovatelné i v př́padě islámských bank.

\section{Ramadán}

Půst je starý semitský zvyk, který se v předislámské Arábii dodržoval z praktických i nutných důvodů. $\mathrm{V}$ bohatších vrstvách ze zdravotních, $\mathrm{v}$ chudších pak z ryze ekonomických. Muhammad sám ho zavedl až v Medíně, aby si naklonil tamní židovské obyvatelstvo. Je to jeden ze sloupů víry, který v islámských zemích dodržuje takřka všechno obyvatelstvo. V dnešním světě je ovšem z praktického hlediska nutné, aby někteří věřící půst nedodržovali. Jedná se o určitě profesní skupiny, které zajiš ují chod zdravého hospodářství a obranyschopnost země. Muslim má povinnost půstu od rozbřesku, kdy pozná bílou nit od černé, do západu slunce. Navíc se musí muslimové vystříhat neshod, neslušných řečí a tělesných rozkoší, některé školy navíc zakazují i kouření, žvýkání tabáku a pití třeba jen doušku vody. Na konci ramadánu už jsou postící se velice vyčerpáni. Proto je ramadán zkouškou vždy nejen pro muslimy, ale pro celé národní hospodářství.

\section{Pou (hadždž) - problém i př́nos Saudské Arábie}

Může-li, měl by každý muslim alespoň jednou za život vykonat pou do Mekky. V dnešní době to už ovšem nejsou jen občané Saudské Arábie, ale poutníci z celého světa. Kvůli tomu bylo v Džiddě postaveno moderní letiště, které v období určeném pro konání poutě přijme kolem stodvaceti letadel denně. Všechny tyto návštěvníky je nutné dopravit do Mekky, což je úkol nesnadný vzhledem k absenci společného jazyka. Pro usnadnění cesty byla v Saudské Arábii vybudována dvě stě kilometrů dlouhá dálnice z Džiddy do Mekky. Okolí Mekky živí turismus, je nutné lidi po dobu pobytu v Mekce zajistit. Hadždž je tak zajímavou ukázkou regionálního rozvoje, kterou musíme připsat pouze na vrub islámu. 


\section{6. Žena a islám}

Německý etnograf Klaus Timm tvrdí, že islám je v současnosti brzdou společenského vývoje především proto, že brání ženě v aktivním zapojení do výrobního procesu. To ale dle jeho tvrzení není vinou islámu, ale spíš podmínek, za jakých se islám rozvinul. Doporučuje hodnotit postavení ženy jako důsledek ryze ekonomických a sociálních pohybů islámské společnosti. ${ }^{11}$ Žena tedy do svého stavu upadla v minulosti a pod vlajkou islámu se z něj nechce, nebo nemůže dostat, čímž islámské ekonomiky ztrácí část svých výrobních faktorů. Jak bylo naznačeno, ženy se mnohdy kloní k ortodoxnějším islámským pravidlům. Islám se pokusil ve 20. století reformovat, ale ekonomická převaha Západního světa mu poskytla pouze impuls, islámské země se postupně pod kulturním a ekonomickým tlakem Západu postupně uchylovaly k čím dál tím radikálnějším politikám a k ortodoxnější víře, čímž samy sebe připravily o možnost růstu. Bylo by chybou domnívat se, že si islámský svět odlišné postavení ženy neuvědomuje. Překážky v kariéře ženy přiznává, ovšem ne nepřekonatelné. Islám chápe ženu jako důležitou součást sociální struktury, tvoří základní jednotku, tedy rodinu, což si islám považuje hodně vysoko ${ }^{12}$. Iránský sociolog Amal Bassám tvrdí: „Islámská společnost zpravidla lpí na svých tradicích a není schopna se jich zbavovat. Přitom jistá modernizace je nutná pro další rozvoj společnosti. Ženská část společnosti se v tomto dilematu zmítá a nikdo není schopen stanovit, jakým směrem se bude vývoj ženské otázky ubírat. ${ }^{13 ،}$

Řešení ženské otázky postupuje vpřed pomalu. V roce 1926 udělal Mustaf Kemal Atatürk razantní krok a přes noc zrušil šarí'u (islámské právo). Pouhé vyhlášení je jen formální krok, který nezajistí jeho dodržování. Na venkově byla dál polygamie a dál se oddávalo v mešitách. Navíc turecké podniky po válce nebyly schopny konkurovat těm západním, způsobený nedostatek míst tak zmařil př́ležitost zapojit ženy do výrobního procesu. Postupným odbouráváním překážek se vydala tuniská vláda, která navíc každý krok dlouhodobě vysvětluje. To se ukazuje jako správná cesta.

\section{Závěr}

I přes jistá specifika jsou islámské bankovnictví a islámské ekonomiky velice dobře životaschopné. Jak se ukazuje, tak praxe, kterou si vyžaduje každodenní život, je silnější než teorie, již hlásají islámští učenci. Přes 75 procent finančních prostředků protéká mimo systém PLS, který je prakticky totožný s konvenčním bankovnictvím. Kde je PLS užíváno, objevují se záruky i garantované výnosy.

V běžném životě tedy naráží islámské státy na ty samé neduhy, s kterými se musí potýkat Západ a jenž se zatím nejlépe podařilo odstranit tržnímu systému. Islám vyzývá své věřící k solidaritě s chudými, je to pravděpodobně jedno z nejsociálnějších náboženství na světě. Jasně se ukazuje, že přílišná solidarita vede k menším ziskům, menším platům a odměnám, tedy $\mathrm{k}$ nepř́liš̌né motivaci a rozpadu organizace.

Nakonec ale bankovní systém končí u toho, že zisky jsou nutné a dozor naprosto nezbytný, protože tam, kde je člověk ponechán bez kontroly, nastává rozkrádání majetku, a už lidé věř́ v cokoli.

11 Islám, ideál a skutečnost, str. 119.

12 http://www.saudinf.com/.

13 Islám, ideál a skutečnost, str.120. 
Je otázkou, jak se budou na ekonomické problémy dívat další generace muslimů. Opětovné zahalování žen do tradičních oděvů i vznik islámských bank se dá považovat za reakci na nejistotu, kterou islámské státy cítily v druhé polovině dvacátého století. Časem by mohla vyrůst generace, která uvidí, že islámské ekonomiky nejsou konkurenceschopné, a budou s tím chtít něco udělat.

Uvědomíme-li si, že islám je náboženství o víc jak šest set let mladší než křes anství, nelze se divit, že není náboženství ve společnosti prosto vlivu. Konec konců za pár let tomu bude šest set let od upálení Mistra Jana Husa za to, že neměl shodné názory s katolickou církví. Proto se dá očekávat v islámských státech vývoj, možná obdobný jako v Evropě, na který bude mít ale vliv díky globalizaci celý svět.

\section{Tabulky}

Trendy v Islámské bance Abu Dhabí (Spojené arabské emiráty - první dvě tabulky) a Islámské bance ABC (třetí tabulka).
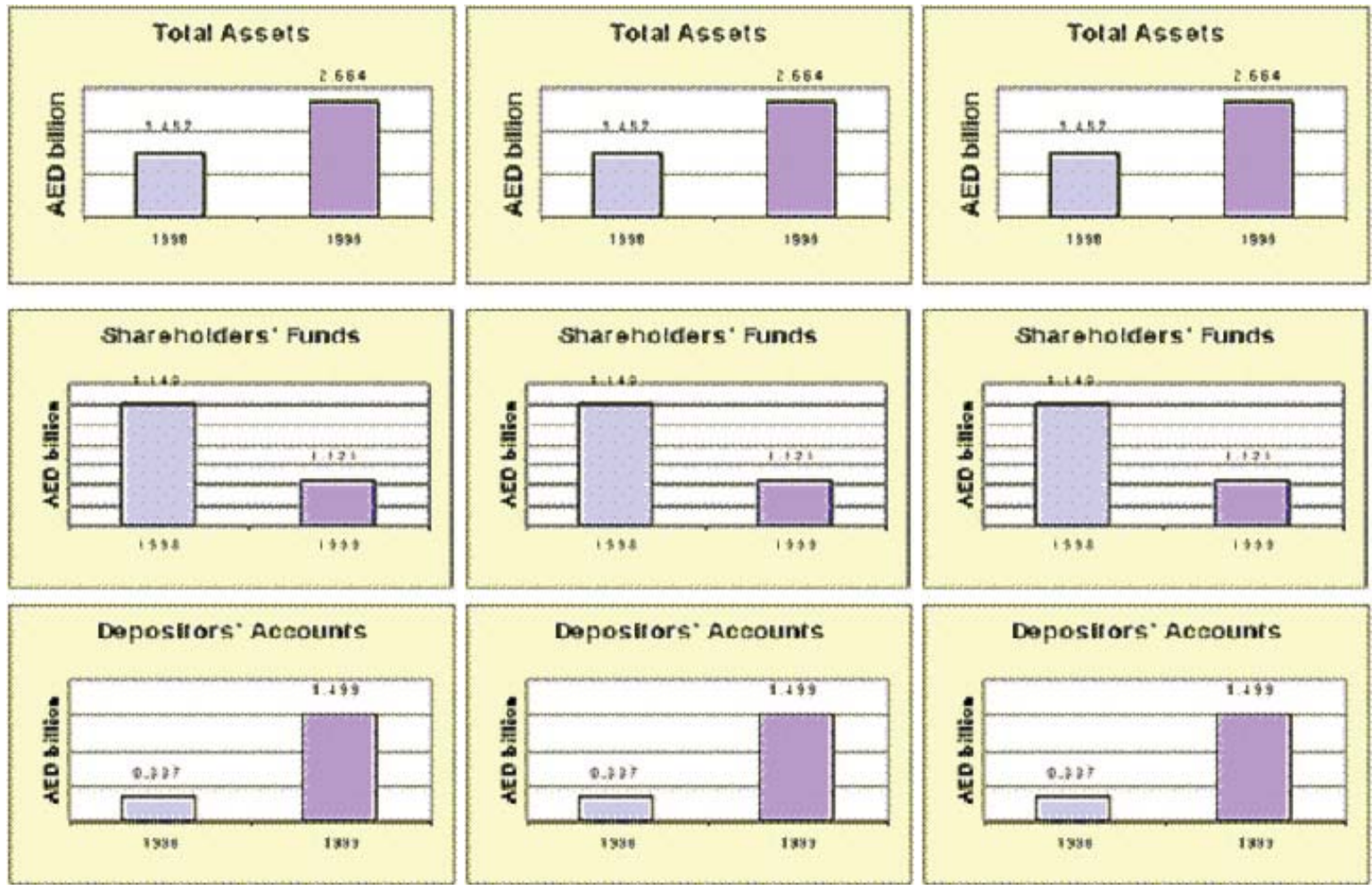

Zdroj: Islámský bankovní institut, http://www.islamic-banking.com/ibanking/reports.php

\section{Literatura}

[1] WEBEROVÁ BABULÍKOVÁ, Gabriela: Islámská ekonomie a bankovnictví, nakladatelství Dar Ibn Rushd, Praha, 2001.

[2] LUCA Errico, MITRA Farahbaksh; Islamic banking: Issues in prudential regulations and supervision; IMF, 1998; http://www.imf.org/external/pubs/ft/wp/wp9830.pdf

[3] Korán, Praha, Odeon, 1991.

[4] KŘIKAVOVÁ Adéla, MENDEL Miloš, MÜLLER Zdeněk, DUDÁK Vladislav: Islám, ideál a skutečnost. Praha, nakladatelství Baset, 2002. 
[5] Článek Pavla Kohouta: Banky podle Alláha, http://www.cs-magazin.com/2005-01/ view.php?article=articles/cs050131.htm

[6] stránky Islámské rozvojové banky: www.isbd.org

[7] informační stránky Saudské Arábie: http://www.saudinf.com/

[8] Institut islámského bankovnictví: http://www.islamic-banking.com 